\title{
Feasibility Study of Grid-Connected PV System for Peak Demand Reduction of a Residential Building in Tehran, Iran
}

\author{
Reza Alayi ${ }^{1 *}$, Mohammed Reyasudin Basir Khan ${ }^{2}$, Mehdi Salehi Ghara Mohmammadi ${ }^{3}$ \\ ${ }^{1}$ Department of Mechanics, Germi Branch, Islamic Azad University, Germi 5651763764, Iran \\ ${ }^{2}$ School of Engineering, Manipal International University, Nilai, Negeri Sembilan 71800, Malaysia \\ ${ }^{3}$ Department of HSE, Energy Institute of Higher Education, Saveh 3917767746, Iran
}

Corresponding Author Email: reza_alayi@iaugermi.ac.ir

https://doi.org/10.18280/mmep.070408

Received: 4 June 2020

Accepted: 30 November 2020

\section{Keywords:}

PV, HOMER, techno-economic analysis, sensitivity analysis, Iran

\begin{abstract}
The use of fossil fuels for energy demand is overgrowing, leading to a higher $\mathrm{CO}_{2}$ emission. Besides, these resources have fluctuating prices and have higher operating costs. Thus, the integration of renewable energy (RE) sources has been increasing throughout the years to reduce the dependency on fossil fuel generation. However, RE generations have high initial costs and intermittent resources. Therefore, it is crucial to conduct technical and economic analysis before the installation of any hybrid energy systems. This study proposes the installation of a PV system for a residential building in Tehran, Iran. The goal of the system is to have a PV system for peak demand reduction. Moreover, the input data also includes economic parameters such as costs of PV, battery, and grid purchases alongside interest rates. Sensitivity analysis also conducted in this study to investigate the variation of load profiles on the optimal system configuration. The simulation results show a $422-\mathrm{kW}$ grid-connected PV system with battery storage is the most optimal system for the selected location. The system has a lower Net Present Cost (NPC) and initial capital compared to other configurations. Moreover, the system also has a higher RE generation and lower energy import from the grid.
\end{abstract}

\section{INTRODUCTION}

Due to the need to use clean energy sources, the use of renewable is increasing over the years [1-3]. Previous works have shown that the integration of RE, such as solar PV, the small hydro, wind, geothermal, and hydrogen, will reduce greenhouse gasses such as $\mathrm{CO}_{2}$. Also, fossil fuels, such as oil, gas, and coal, have variable prices and costly to operates $[4,5]$. Hence, many countries take more serious action into the use of alternative energy sources such as RE [5-8]. The use of RE generations such as solar energy, wind, geothermal, hydrogen, and biomass requires technical and economic studies before installation to have an optimal configuration leading to a more efficient system [9]. RE is the most promising solution for developing countries and areas with limited access to electricity. Therefore, many programs and policies have been developed to increase RE into their country energy mix [1012]. However, the adaptation of these energy sources to the current conventional energy generations has still been overwhelmed with problems such as higher costs and intermittent resources.

There have been many works related to feasibility study RE and hybrid system installation. For example, Shaahid et al. have conducted a study of techno-economic evaluation of offgrid hybrid photovoltaic-diesel-battery power systems for rural electrification in Saudi Arabia [13]. Meanwhile, AlMasri et al. perform a feasibility investigation of a hybrid ongrid wind photovoltaic retrofitting system [14]. Ahmed et al. have conducted work related to a stand-alone hybrid generation system that combines solar photovoltaic and wind turbine with maximum power point tracking control [15].

In addition, Al-Sharafi et al. worked-on techno-economic analysis and optimization of solar and wind energy systems for power generation and hydrogen production in Saudi Arabia [16]. Baghdadi et al. have conducted a feasibility study and energy conversion analysis of stand-alone hybrid RE systems [17]. Khalili et al. investigate the optimal hybrid system comprises of a grid-connected PV system in Ardabil city [18]. Alayi et al. have provided conducted work on the optimization and evaluation of wind, solar, and fuel cell hybrid system to meet the load demand in a remote area [19]. Kazem and et all study the effect of environmental variables on photovoltaic performance-based on experimental studies [20]. Moreover, Maatallah et al. explore the assessment viability for hybrid energy systems (PV/wind/diesel) with storage in the northernmost city in Africa, Bizerte, Tunisia [21]. Vasel et al. conducted a study on the effect of wind direction on the performance of solar PV plants [22]. Yu et al. perform a study on the sizing of hybrid energy systems [23] Moreover, M.R.B Khan et al. conducted feasibility studies for hybrid PV and micro-hydro systems for a resort island in Malaysia based on seasonal load demand [24-26].

In this study, the feasibility analysis of PV system installation for a residential building has been conducted based on the techno-economic analysis. it is crucial to conduct technical and economic analysis before the installation of any hybrid energy systems. This study proposes the installation of a PV system for a residential building in Tehran, Iran. The goal 
of the system is to have a PV system for peak demand reduction. Moreover, the input data also includes economic parameters such as costs of PV, battery, and grid purchases alongside interest rates. Sensitivity analysis also conducted in this study to investigate the variation of load profiles on the optimal system configuration the rest of the papers are structured as follows: Section 2 described the data collected for this study. Meanwhile, Section 3 presents the technical and economic analysis that includes the system model and design. Section 4 demonstrates the results obtained, such as optimal configurations and sensitivity analysis. Finally, Section 5 summarizes the work and findings.

\section{DATA COLLECTION}

The selected location for this study is a 40-story residential building located in Mehrabad, Tehran, Iran, at $36.7^{\circ} \mathrm{N}$ and $51.4^{\circ} \mathrm{E}$. The location of the case study is shown in Figure 1.

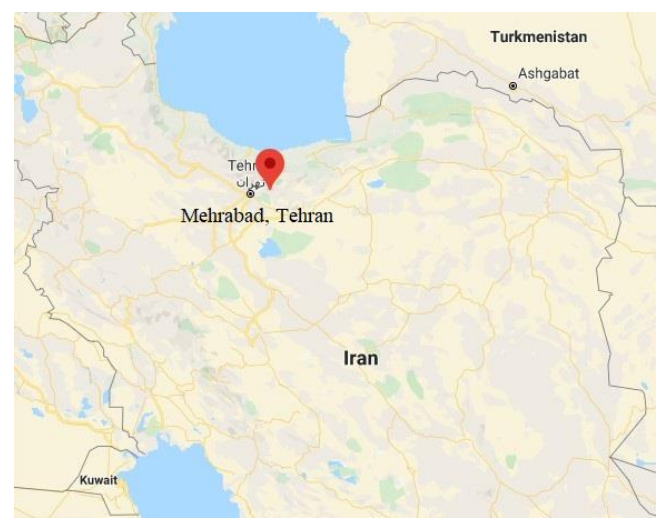

Figure 1. Location of Mehrabad, Tehran [Source: edited from Google Maps]

\subsection{Load profile}

The load profile was obtained based on the modeled building in TRNSYS. The building characteristics are as follow:

- 40 story building with two units on each floor with an area of $130 \mathrm{~m}^{2}$

- $\quad$ Each unit has an average of three occupants

- Each unit has two bedrooms and a kitchen with an area of $12 \mathrm{~m}^{2}$ and $15 \mathrm{~m}^{2}$, respectively.

The average daily load profile for the residential building is shown in Figure 2. Meanwhile, the seasonal load demand throughout the year is shown in Figure 3. Each unit has an estimated average of $860 \mathrm{kWh}$ of energy consumption per month. The building has an average load of $50.8 \mathrm{~kW}$ with a peak of up to $286 \mathrm{~kW}$.

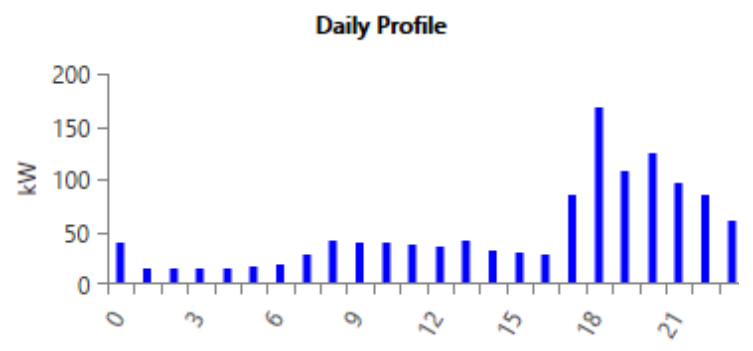

Figure 2. Daily load profile

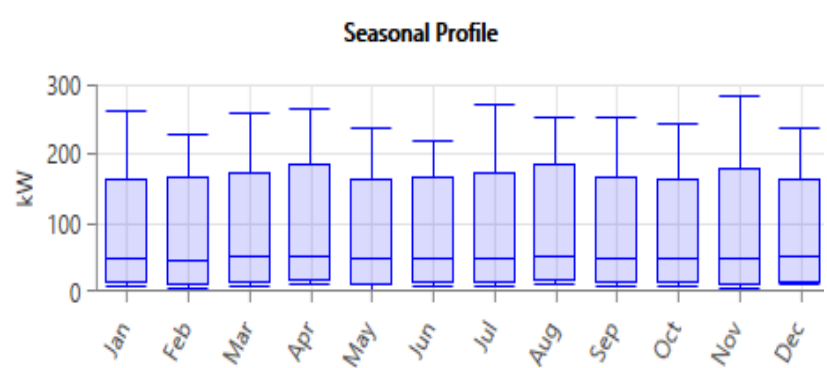

Figure 3. Seasonal load profile

\subsection{Solar radiation}

In this study, the solar radiation data in Mehrabad was collected from the NASA POWER database. Solar radiation data is crucial to determine the potential generation from PV systems at the location. The amount of average solar radiation in this area is $4.89 \mathrm{kWh} / \mathrm{m}^{2} / \mathrm{d}$. The solar radiation profile is illustrated in Figure 4.

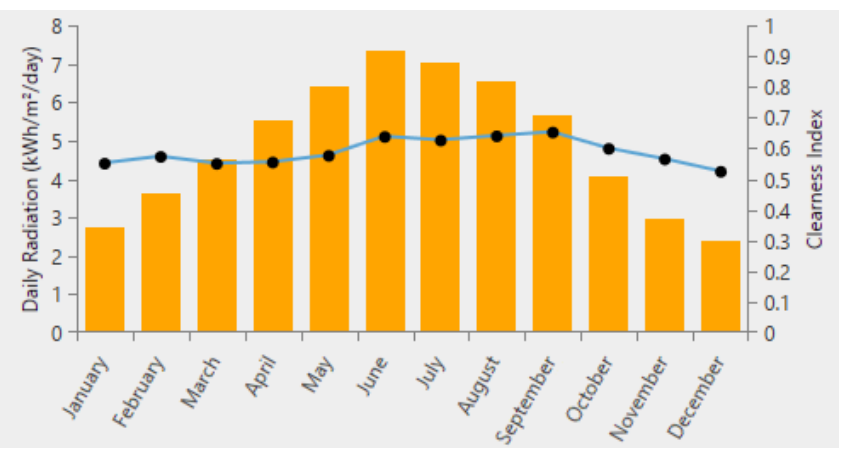

Figure 4. Average monthly solar radiation in Mehrabad, Tehran

\subsection{System model}

HOMER was used to determine the feasibility of PV system installation on-site. The software tool is expected to show the technical and economic parameters for the optimal system configurations. The system modeled comprises of PV, battery, converter, and grid. The HOMER model is presented in Figures 5 and 6 . Both PV and battery storage systems are connected to the DC bus. The inverter system is used to convert the DC output from PV and battery to the AC linked grid and load. The systems' technical and economic parameters are presented in Table 1.

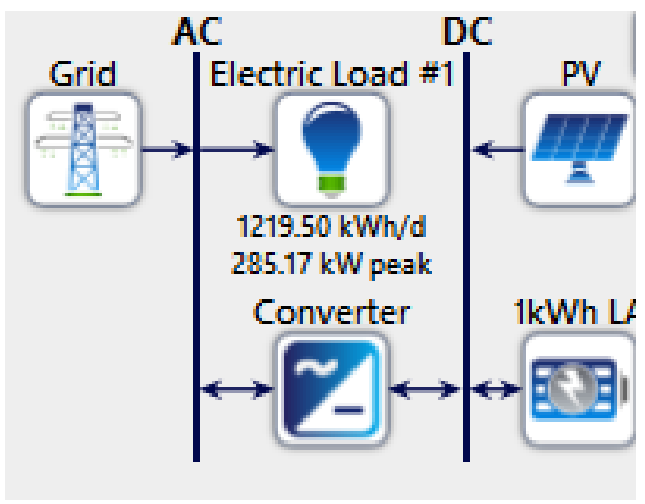

Figure 5. Hybrid System Model in HOMER scenario 1 


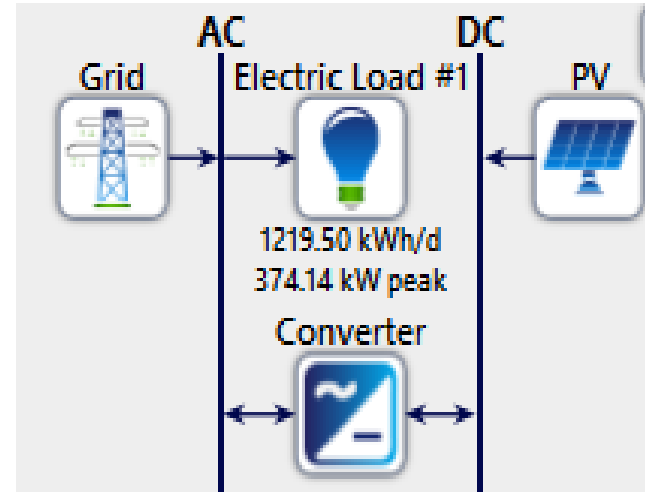

Figure 6. Hybrid System Model in HOMER scenario 2

Table 1. Technical and economic parameters [23, 24]

\begin{tabular}{|c|c|c|}
\hline No & Components & Specifications \\
\hline \multirow[t]{6}{*}{1} & PV System & \\
\hline & Size considered $(\mathrm{kW})$ & $\begin{array}{c}0 \text { to } 700 \mathrm{~kW} \text { with } 20 \mathrm{~kW} \\
\text { step size }\end{array}$ \\
\hline & Capital cost $(\$ / W)$ & 3.64 \\
\hline & Replacement cost $(\$ / W)$ & 3.64 \\
\hline & $\begin{array}{l}\text { Operation and maintenance } \\
\text { cost (\$/year) }\end{array}$ & 329 \\
\hline & Lifetime (Years) & 25 \\
\hline \multirow[t]{5}{*}{2} & Inverter & \\
\hline & Size considered $(\mathrm{kW})$ & $\begin{array}{c}0 \text { to } 700 \mathrm{~kW} \text { with } 20 \mathrm{~kW} \\
\text { step size }\end{array}$ \\
\hline & Capital cost $(\$ / W)$ & 1.05 \\
\hline & Replacement cost $(\$ / \mathrm{W})$ & 1.05 \\
\hline & $\begin{array}{l}\text { Operation and maintenance } \\
\text { cost }(\$)\end{array}$ & 10,500 \\
\hline \multirow[t]{7}{*}{3} & Batteries & \\
\hline & Model & Generic \\
\hline & Batteries per string & 100 \\
\hline & Sizes considered & Up to $2,000 \mathrm{kWh}$ \\
\hline & Capital cost (\$/battery) & 1,200 \\
\hline & Replacement cost (\$/battery) & 1,200 \\
\hline & $\begin{array}{l}\text { Operation and maintenance } \\
\text { cost (\$/year) }\end{array}$ & 10 \\
\hline
\end{tabular}

\section{SECTION HEADINGS TECHNICAL AND ECONOMIC ANALYSIS}

\subsection{PV system}

The PV system modeled with sizes varied from 0 to $700 \mathrm{~kW}$ with a step size of $20 \mathrm{~kW}$. This building-integrated PV (BIPV) system is limited to $700 \mathrm{~kW}$ only due to limited space and area of installation. The cost considered also comprises of Balance of System (BOS) as well.

\subsection{Battery storage system}

The battery storage system modeled with sizes varies from 0 to $700 \mathrm{~kW}$ with a step size of $20 \mathrm{~kW}$. A generic battery model was used to simulate the battery storage system.

\subsection{Grid}

Grid is the primary source to meet the load demand. The grid rate in Tehran, Iran, is 0.7 cents $/ \mathrm{kWh}$ price with $0.05 \$ / \mathrm{kWh}$ sellback.

\subsection{Energy management system}

Both Load Following (LF) and Cycle Charging (CC) were considered for the system controls. HOMER will perform decision making based on the best control method that produces higher RE generations with lower cost.

\section{RESULTS}

\subsection{Optimization results}

The optimization results are presented in Table 2. The results indicate PV-battery-grid system is the most optimal configuration followed by PV-grid and grid the only system. Only PV-battery-grid and PV-grid system will be compared and discussed since the goal of this work are to determine the optimal configuration and sizing of a grid-connected PV system for the building.

Although, the initial capital of the PV-battery-grid system is $1.07 \$ \mathrm{M}$, which is $56 \%$ higher than the PV-grid system. The PV-battery-grid configurations have the lowest NPC at 2.16\$M (million) followed by PV-grid and grid only with NPC of $2.30 \$ \mathrm{M}$ and $2.88 \$ \mathrm{M}$, respectively. Additionally, the Cost of Energy (COE) for the PV-battery-grid system is $0.257 \$ / \mathrm{kWh}$, which is lower compared to the PV-grid system. Moreover, the operation cost for the PV-battery-grid system is lower than the PV-grid system at $84,372 \$$ and $141 \$, 421 \$$, respectively. The optimal system has an LF control strategy.

Meanwhile, other configurations used $\mathrm{CC}$ as the control strategy. LF energy management is where the generator only produces sufficient power to meet the demand. Whereas in CC strategy, the generator will operate at full capacity, and the excess generation will be used to charge the battery storage system.

The PV-battery-grid system also has higher RE penetration with 90\% PV generation. However, the PV-grid system has only $53 \%$ RE generation due to a lack of storage system. The electricity production of each system is shown in Figure 7.

\subsection{Sensitivity analysis}

The sensitivity variable chosen is load profile growth. The load profile growth effect on the optimal system sizing and configuration was simulated in HOMER. The sensitivity analysis results are shown in Table 3. The results show the system configuration varies as the load profile increases. The PV and battery sizes needed to become more substantial as the load becomes bigger. However, the system will import more energy from the grid contributing to lesser RE penetration as the load profile grows.

Table 2. Optimization results

\begin{tabular}{cccccccccc}
\hline Rank & PV (kW) & $\begin{array}{c}\text { Battery } \\
\mathbf{( k W h )}\end{array}$ & $\begin{array}{c}\text { Conv. } \\
\mathbf{( k W )}\end{array}$ & $\begin{array}{c}\text { Grid } \\
\mathbf{( k W )}\end{array}$ & $\begin{array}{c}\text { Dispatch } \\
\text { Strategy }\end{array}$ & Initial capital (\$) & $\begin{array}{c}\text { NPC } \\
\mathbf{( \$ )}\end{array}$ & $\begin{array}{c}\text { COE } \\
\mathbf{( \$ / k W h )}\end{array}$ & RF \\
\hline 1 & 422 & 1,603 & 270 & 1000 & LF & $1.07 \mathrm{M}$ & $2.16 \mathrm{M}$ & 0.257 & 0.901 \\
2 & 237 & - & 193 & 1000 & CC & 468,776 & $2.30 \mathrm{M}$ & 0.263 & 0.530 \\
3 & - & - & - & 1000 & CC & 0 & $2.88 \mathrm{M}$ & 0.500 & 0.000 \\
\hline
\end{tabular}



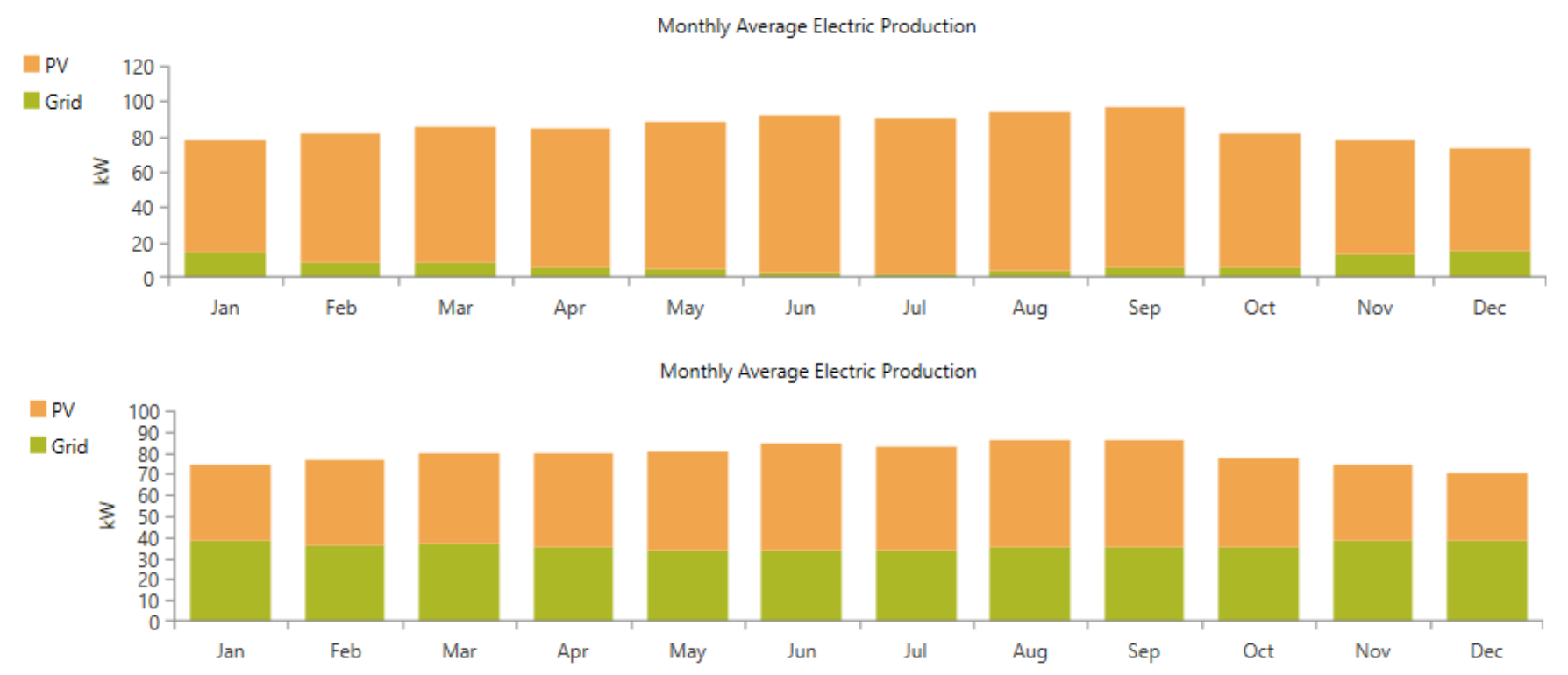

Figure 7. Monthly average electricity production a) PV-battery-grid system b) PV-battery system

Table 3. Sensitivity analysis results

\begin{tabular}{cccccccccc}
\hline Load (kWh/d) & $\mathbf{P V}(\mathbf{k W})$ & $\begin{array}{c}\text { Battery } \\
(\mathbf{k W h})\end{array}$ & $\begin{array}{c}\text { Conv. } \\
(\mathbf{k W})\end{array}$ & $\begin{array}{c}\text { Grid } \\
\mathbf{( k W )}\end{array}$ & $\begin{array}{c}\text { Dispatch } \\
\text { Strategy }\end{array}$ & Initial capital (\$) & $\begin{array}{c}\text { NPC } \\
\mathbf{( \$ )}\end{array}$ & $\begin{array}{c}\text { COE } \\
(\mathbf{\$} / \mathbf{k W h})\end{array}$ & $\mathbf{R F}$ \\
\hline 1,220 & 422 & 1,603 & 270 & 1000 & LF & $1.07 \mathrm{M}$ & $2.16 \mathrm{M}$ & 0.257 & 0.901 \\
1,320 & 448 & 1,734 & 283 & 1000 & LF & $1.14 \mathrm{M}$ & $2.34 \mathrm{M}$ & 0.261 & 0.897 \\
1,440 & 486 & 1,892 & 309 & 1000 & LF & $1.24 \mathrm{M}$ & $2.55 \mathrm{M}$ & 0.262 & 0.896 \\
1,600 & 551 & 2,083 & 351 & 1000 & LF & $1.39 \mathrm{M}$ & $2.83 \mathrm{M}$ & 0.257 & 0.898 \\
\hline
\end{tabular}

\section{CONCLUSIONS}

This work goal is to determine the optimal configuration of a grid-connected PV system to lower the peak demand for a residential building. HOMER software was used to model and simulate the system. The results show grid-connected $422 \mathrm{~kW}$ $\mathrm{PV}$ with battery storage is the most optimal configuration for the selected location. The system has an NPC of $2.16 \$ \mathrm{M}$ and initial capital of $1.07 \$ \mathrm{M}$, which is $6 \%$ lower than other configurations. Moreover, the system also has a lower COE with $0.2547 \$ / \mathrm{kWh}$.

\section{ACKNOWLEDGMENT}

The author would like to thank Islamic Azad University (Germi Branch), Iran and Manipal International University, Malaysia, for providing resources needed for this work.

\section{REFERENCES}

[1] Alayi, R., Kasaeian, A., Atabi, F. (2019). Thermal analysis of parabolic trough concentration photovoltaic/thermal system for using in buildings. Environmental Progress \& Sustainable Energy, 38(6): 13220. https://doi.org/10.1002/ep.13220

[2] Kasaeian, A., Shamel, A., Alayi, R. (2015). Simulation and economic optimization of wind turbines and photovoltaic hybrid system with storage battery and hydrogen tank (case study the city of Yazd). Journal of Current Research in Science, 3(5): 105.

[3] Nawaz, S., Tandon, A. (2018). Power loss minimisation of rural feeder of Jaipur city by renewable-based DG technologies. Australian Journal of Electrical and Electronics Engineering, 15(1-2): 53-60. https://doi.org/10.1080/1448837X.2018.1500667

[4] Alayi, R., Sobhani, E., Najafi, A. (2020). Analysis of environmental impacts on the characteristics of gas released from biomass. Anthropogenic Pollution Journal, 4(1):

$1-14$. https://doi.org/10.22034/ap.2020.1879800.1052

[5] Wang, Q., Wang, L. (2020). Renewable energy consumption and economic growth in OECD countries: A nonlinear panel data analysis. Energy, 207: 118200. https://doi.org/10.1016/j.energy.2020.118200

[6] Wojuola, R.N., Alant, B.P. (2019). Sustainable development and energy education in Nigeria. Renewable Energy, 139: 1366-1374. https://doi.org/10.1016/j.renene.2019.03.010

[7] Ganguly, P., Kalam, A., Zayegh, A. (2019). Fuzzy logicbased energy management system of stand-alone renewable energy system for a remote area power system. Australian Journal of Electrical and Electronics Engineering, 16(1): 21-32. https://doi.org/10.1080/1448837X.2019.1588091

[8] Hu, B., Sathiakumar, S. (2014). A new interleaving technique based on current ripple reduction of paralleled converters for renewable systems. Australian Journal of Electrical and Electronics Engineering, 11(1): 41-54. https://doi.org/10.7158/E13-011.2014.11.1

[9] Dang, C., Wang, X., Shao, C., Wang, X. (2019). Distributed generation planning for diversified participants in demand response to promote renewable energy integration. Journal of Modern Power Systems and Clean Energy, 7(6): 1559-1572. 
https://doi.org/10.1007/s40565-019-0506-9

[10] Alayi, R., Kasaeian, A., Atabi, F. (2020). Optical modeling and optimization of parabolic trough concentration photovoltaic/thermal system. Environmental Progress \& Sustainable Energy, 39(2): e13303. https://doi.org/10.1002/ep.13303

[11] Whitcraft, A.K., Becker-Reshef, I., Justice, C.O., Gifford, L., Kavvada, A., Jarvis, I. (2019). No pixel left behind: Toward integrating earth observations for agriculture into the united nations sustainable development goals framework. Remote Sensing of Environment, 235: 111470. https://doi.org/10.1016/j.rse.2019.111470

[12] Mustafayev, R.I., Hasanova, L.H., Musaev, M.M. (2018). Using regulated electrical machines in small hydropower plants operating in a power network. Russian Electrical Engineering, 89(5): https://doi.org/10.3103/S1068371218050061

[13] Shaahid, S.M., El-Amin, I. (2009). Techno-economic evaluation of off-grid hybrid photovoltaic-diesel-battery power systems for rural electrification in Saudi Arabiaa way forward for sustainable development. Renewable and Sustainable Energy Reviews, 13(3): 625-633. https://doi.org/10.1016/j.rser.2007.11.017

[14] Al-Masri, H.M., Ehsani, M. (2015). Feasibility investigation of a hybrid on-grid wind photovoltaic retrofitting system. IEEE Transactions on Industry $\begin{array}{lll}\text { applications, } & \text { 52(3): }\end{array}$ https://doi.org/10.1109/IAS.2015.7356802

[15] Ahmed, N.A., Miyatake, M. (2006). A stand-alone hybrid generation system combining solar photovoltaic and wind turbine with simple maximum power point tracking control. In 2006 CES/IEEE 5th International Power Electronics and Motion Control Conference, pp. 1-7. https://doi.org/10.1109/IPEMC.2006.4777984

[16] Al-Sharafi, A., Sahin, A.Z., Ayar, T., Yilbas, B.S. (2017). Techno-economic analysis and optimization of solar and wind energy systems for power generation and hydrogen production in Saudi Arabia. Renewable and Sustainable $\begin{array}{lll}\text { Energy } & \text { Reviews, } & \text { 69: }\end{array}$ https://doi.org/10.1016/j.rser.2016.11.157

[17] Baghdadi, F., Mohammedi, K., Diaf, S., Behar, O. (2015). Feasibility study and energy conversion analysis of stand-alone hybrid renewable energy system. Energy Conversion and Management, 105: 471-479. https://doi.org/10.1016/j.enconman.2015.07.051

[18] Khalili, H., Arash, A., Alayi, R. (2015). Simulation and economical optimization hybrid system PV and grid in
Ardabil city. Journal of Current Research in Science, 3(5): 83-91.

[19] Alayi, R., Kasaeian, A., Najafi, A., Jamali, E. (2019). Optimization and evaluation of a wind, solar and fuel cell hybrid system in supplying electricity to a remote district in national grid. International Journal of Energy Sector Management, $14(2)$ : 408-418. https://doi.org/10.1108/IJESM-04-2019-0019

[20] Kazem, H.A., Chaichan, M.T. (2016). Effect of environmental variables on photovoltaic performancebased on experimental studies. International Journal of Civil, Mechanical and Energy Science (IJCMES), 2(4): 1-8.

[21] Maatallah, T., Ghodhbane, N., Nasrallah, S.B. (2016). Assessment viability for hybrid energy system (PV/wind/diesel) with storage in the northernmost city in Africa, Bizerte, Tunisia. Renewable and Sustainable Energy Reviews, 59: 1639-1652. https://doi.org/10.1016/j.rser.2016.01.076

[22] Vasel, A., Iakovidis, F. (2017). The effect of wind direction on the performance of solar PV plants. Energy Conversion and Management, 153: 455-461. https://doi.org/10.1016/j.enconman.2017.09.077

[23] Yu, H., Zhang, C., Deng, Z., Bian, H., Sun, C., Jia, C. (2018). Economic optimization for configuration and sizing of micro integrated energy systems. Journal of Modern Power Systems and Clean Energy, 6(2): 330341. https://doi.org/10.1007/s40565-017-0291-2

[24] Khan, M.R.B., Jidin, R., Pasupuleti, J., Shaaya, S.A. (2014). Micro-hydropower potential assessment and generation volatility due to seasonal climate. In 2014 IEEE International Conference on Power and Energy (PECon), pp. 371-376. https://doi.org/10.1109/PECON.2014.7062473

[25] Khan, M.R.B., Pasupuleti, J., Jidin, R. (2018). Load frequency control for mini-hydropower system: A new approach based on self-tuning fuzzy proportionalderivative scheme. Sustainable Energy Technologies and Assessments, 30: 253-262. https://doi.org/10.1016/j.seta.2018.10.013

[26] Khan, M.R.B., Jidin, R., Pasupuleti, J., Shaaya, S.A. (2014). Optimal combinations of PV, wind, micro-hydro and diesel systems for a seasonal load demand. In 2014 IEEE International Conference on Power and Energy (PECon), pp. 171-176. 